\title{
Peran Syekh H. Imam Sabar Al-Kholidi dalam Perkembangan Tarekat Naqsyabandiyah di Onder Distrik Mandau Kerajaan Siak
}

\author{
Nur Rahmawati Busyro' ${ }^{1}$, Yuliantoro ${ }^{2}$, Asyrul Fikri ${ }^{3}$ \\ ${ }^{1,2,3}$ Pendidikan Sejarah, FKIP, Universitas Riau \\ nur.rahmawati1141@student.unri.ac.id \\ yuliantoro@lecturer.unri.ac.id \\ asyrul.fikri@lecturer.unri.ac.id
}

\begin{abstract}
Abstrak
Penelitian ini bertujuan untuk menelusuri sejarah tarekat Naqsyabandiyah Distrik Mandau Kesultanan Siak dengan memfokuskan kajian pada peranan Tuan Syekh H. Imam Sabar Al-Kholidi Naqsyabandi Bin Encik Coteih dalam mengembangkan ajaran Islam jalur tarekat Naqsyabandiyah di onder distrik Mandau tepatnya di desa Balai Pungut. Metode penelitian menggunakan pendekatan deskriptif dengan teknik pengumpulan data melalui observasi dan wawanacara. Hasil penelitian menunjukkan bahwa tarekat Naqsyabandiyah berkembang dan diamalkan di Indonesia pada abad ke-19. Kerajaan Siak menjadi pusat berkembangnya ajaran tarekat Naqsyabandiyah di Riau. Desa Balai Pungut menjadi saksi nyata berkembangnya ajaran tarekat Naqsyabandiyah di wilayah Mandau pada masa Kerajaan Siak Sri Indrapura oleh Tuan Syekh H. Imam Sabar Al-Kholidi Naqsyabandi bin Encik Coteih. Tarekat Naqsyabandiyah untuk pertama kalinya mulai berjalan dan dipimpin langsung oleh Syekh H. Imam Sabar Al-Kholidi Naqsyabandi pada tahun 1925 di desa Beringin. Kemudian baru pada tahun 1936 diajarkan dan dikembangkan di desa Balai Pungut.
\end{abstract}

Kata Kunci: Sejarah, Tarekat Naqsyabandiyah, Syekh H. Imam Sabar Al-Kholidi

\begin{abstract}
This study aims to trace the history of the Naqsyabandi tarekat in the Mandau District of the Siak Sultanate by focusing on the role of Tuan Syekh H. Imam Sabar Al-Kholidi Naqsyabandi Bin Encik Coteih in developing Islamic teachings through the Naqsyabandiyah tarekat in the onder district of Mandau, precisely in Balai Pungut village. The research method is a qualitative descriptive approach with a simple analysis by observation and interviews. The results showed that the Naqsyabandiyah tarekat developed and was practised in Indonesia in the 19th century. The Siak kingdom became the centre of the Naqsyabandiyah tarekat in Riau. Balai Pungut Village is an authentic witness to the development of the Naqsyabandiyah Order in the Mandau area during the Siak Sri Indrapura Kingdom by Tuan Syekh H. Imam Sabar Al-Kholidi Naqsyabandi bin Encik Coteih. The Naqsyabandiyah Order began to be established and was led directly by Sheikh H. Imam Sabar Al-Kholidi Naqsyabandi for the first time, namely in 1925 in the village of Beringin and only in 1936 was it taught and developed in the town of Balai Pungut.
\end{abstract}

Keywords: History, Naqsyabandiyah Order, Syekh H. Imam Sabar Al-Kholidi 


\section{Pendahuluan}

Sejarah merupakan sebuah cabang ilmu yang menceritakan tentang peristiwaperistiwa yang benar-benar terjadi dalam kehidupan manusia pada masa lampau. Sejarah yang didefinisikan sebagai suatu peristiwa yang menjadikan manusia sebagai objeknya ini pasti akan meninggalkan bukti-bukti peristiwa serta nilai-nilai kemanusiaan yang terkandung di dalamnya. Menurut Kartodirdjo sejarah dapat mengembangkan kepribadian bagi yang mempelajarinya. Dengan mempelajari sejarah, kita tidak akan mudah terjebak karena terbiasa berpikir kritis, analitis, dan rasional serta didukung oleh fakta (Madjid \& Wahyudhi, 2014: 12).

Indonesia telah melalui perjalanan sejarah yang sangat panjang. Termasuk didalamnya terkait sejarah penyebaran Islam di Indonesia. Penyebaran Islam di Melayu, termasuk Nusantara, diakui oleh sebagian besar ahli menggunakan pendekatan sufistik dimana sebagian besar penduduk berhasil diislamkan. Aspek utama keberhasilan akan hal tersebut adalah kemampuan atau keahlian para sufi memperlihatkan Islam dalam bentuk yang atraktif, terkhusus dengan menitikkan perubahan dalam kepercayaan dan praktek keagamaan lokal. Bagi 'Abbas Muhammad 'Aqqad, Indonesia menjadi tempat paling baik untuk membuktikan fakta bahwa Islam diterima dan berkembang di tengah-tengah penduduk yang menganut agama lain. Di setiap penjuru negeri terdapat bukti nyata betapa keteladanan yang baik berperan dalam penyebaran Islam tanpa menggunakan kekerasan (Suteja, 2016: 11).

Ragam pemikiran dan pelaksanaan praktek keagamaan Islam di Indonesia pada awalnya identik dengan kesufian (tasawuf). Bukti nyata akan hal tersebut dapat dilihat dari sosok pemimpin spiritual yang lazim disebut dengan guru-guru sufi atau mursyid dan khalifah tarekat. Al-Tashawwuf al-Islami wa Atsaruhu fi al-Tashawwuf al-Indunisiy alMu'ashir (Islam Sufistik, Islam Pertama dan Pengaruhnya hinggi Kini di Indonesia), adalah hasil kajian intensif Alwi Syihab dalam karya disertasinya. Perkembangan dan penyebaran agama Islam tidak dapat kita pisahkan dari sufisme dan tarekat (Shihab, 2001). Bahkan, berdasarkan data yang saya baca, Islam sufistik sesungguhnya merupakan Islam pertama yang dikenal di Indonesia, Malaysia, Thailand selatan, Filipina selatan dan Kamboja. Dalam perkembangannya, sufisme terpolarisasi dalam tiga kutub yaitu tashawwuf sunni (ortodoks), sufisme falsafi (heterodoks) dan sufisme kompromistik (mempertemukan tasawuf sunni dan falsafi) (Abduh, 2012: 207). 
Melihat negara Indonesia sendiri terdapat bermacam-macam tarekat serta organisasi yang mirip tarekat. Sebagian ada yang merupakan tarekat lokal, bahkan banyak kelompok kelompok kebatinan yang kelihatannya bersifat anti-Islam serta mengatakan bahwa mereka berasal dari kepercayaan leluhur, ternyata dipengaruhi oleh tarekat. Tarekat jika ditinjau dari bahasa diartikan sebagai jalan, cara, garis, kedudukan, keyakinan dan agama. Dalam pembahasan masalah dasar hukum tarekat ini, sebenarnya dapat dilihat dari makna terminologi bahwa tarekat adalah perjalanan seseorang/pengikut tarekat menuju tuhan dengan cara mensucikan diri atau perjalanan yang harus ditempuh secara rohani, melalui beberapa segi yang terdapat di dalamnya, sehingga dari sini akan dapat diketahui secara jelas tentang kedudukan hukumnya dalam Islam (Iskandar, 2018: 2).

Tarekat Naqsyabandiyah merupakan salah satu tarekat yang berpengaruh di dunia. Tarekat ini tersebar hampir di seluruh penjuru dunia Islam, baik Timur maupun Barat. Perkembangan dan pertumbuhan Tarekat Naqsyabandiyah ini berkaitan dengan kewajiban setiap khalifah terlibat aktif menyebarluaskannya. Sebab, merupakan kewajiban sesuai dengan amanah yang diterima dari para mursyid yang menjadi perantara dan mengajarkan Tarekat Naqsyabandiyah, terus menerus diwariskan sampai saat ini (Hidayat, 2015: iii).

Kerajaan Siak (berasal dari kata syekh dalam bahasa Arab yaitu orang yang alim dalam bidang agama Islam) misalnya, peran penting Sultan dalam pengembangan Islam di daerah ini seperti memberikan kesempatan kepada berbagai kelompok keislaman baik untuk berdakwah maupun dalam kegiatan pendidikan. Di antara berbagai kelompok keislaman itu adalah Islam yang identik dengan tarekat, suatu paham atau aliran keagamaan yang sampai saat ini hampir di berbagai wilayah dalam daerah bekas kekuasaan Sultan Siak masih terkenal dan terus dikembangkan serta dijalankan melalui kegiatan suluk. Usaha yang dilakukan Sultan Siak untuk mengajak orang-orang tarekat Naqsyabandiyah memiliki dua tujuan. Pertama, untuk mengajar serta mendidik diberbagai lembaga pendidikan serta kedua, untuk tujuan khusus yaitu mengembangkan ajaran tarekat. Berdasarkan registrasi guru agama pada tahun 1930 terdapat 57 orang guru yang mendapat izin untuk mengajar pada tiga Distrik, masing-masing yaitu 44 guru pada Distrik Bagan Siapi-api, 8 guru pada Distrik Pekanbaru, 5 guru pada Distrik Selat Panjang (termasuk di dalamnya distrik Mandau) dan 29 dari semuanya adalah guru-guru yang mengajarkan tarekat (Abduh, 2009: 384). 
Berdasarkan fakta tersebut maka jelas bahwa Sultan telah memberikan peluang yang sangat besar bagi berkembang dan tumbuhnya paham tarekat, sehingga tarekat Naqsabandiyah menjadi organisasi atau wadah keagaaman terbesar serta tersebar di berbagai daerah daratan setelah sekian lama berkembang di Riau. Dukungan dan dorongan yang besar dari Sultan merupakan faktor yang memiliki andil besar yang menyebabkan ajaran tarekat Naqsyabandiyah sampai saat ini masih mewarnai aliran atau paham keagamaan di berbagai lapisan masyarakat. Salah satu daerah yang terkena alur penyebaran tarekat Naqsyabandiyah ini adalah Distrik Mandau tepatnya di desa Balai Pungut pada masa Kerajaan Siak. Syekh yang terkenal dalam mengajarkan ajaran ini adalah tuan syekh H. Imam Sabar Al-Kholidi Naqsyabandi bin Encik Coteih.

Kajian-kajian terdahulu yang berkaitan dengan sejarah tarekat Naqsyabandiyah di beberapa daerah kekuasaan kerajaan Siak telah ada dilakukan oleh beberapa peneliti. Namun belum ada yang mengkaji terkait dengan judul yang penulis angkat. Beberapa penelitian tersebut adalah pertama, penelitian Abduh (2009) lebih mengkaji terkait dengan akar sejarah serta aktivitas jamaah tarekat Naqsyabandiyah di kabupaten Pelalawan. Kedua, penelitian Abduh (2012) lebih memfokuskan kajian pada peran tarekat Naqsyabandiyah Khalidiyyah Syekh Abdul Wahab Rokan (dalam dakwah dan pendidikan Islam di Riau dan Sumut) dimana Rokan ini merupakan salah satu dari beberapa daerah kekuasaan kerajaan Siak pada saat itu tepatnya merupakan bagian dari distrik Bagan Siapiapi. Ketiga, penelitian Amrizal (2019) lebih meneliti terkait keberadaan tarekat Naqsyabandiyah dan pengaruhnya terhadap kehidupan sosial budaya masyarakat sakai di Kabupaten Bengkalis. Pada penelitian ini memang ada menyinggung peran tuan Syekh $\mathrm{H}$. Imam Sabar Al-Kholidi Naqsyabandi bin Encik Coteih namun, tidak menjelaskan secara lebih mendalam dan luas. Keempat, penelitian Siregar (2011) yang kembali menitikkan pada tarekat Naqsyabandiyah oleh Syaikh Abdul Wahab Rokan dimulai dari sejarah, ajaran, amalan dan dinamika perubahan yang terjadi.

Pada umumnya, karya-karya yang dijadikan sebagai tinjauan pustaka terhadap penelitian yang berkaitan dengan sejarah tarekat Naqsyabandiyah di Kerajaan Siak ini lebih memfokuskan pada peranan Syekh Abdul Wahab Rokan distrik Bagan Siapi-api. Adapun penelitian ini memfokuskan kepada sejarah tarekat Naqsyabandiyah distrik Mandau Kerajaan Siak yang menitikkan pada peranan tuan Syekh H. Imam Sabar AlKholidi Naqsyabandi bin Encik Coteih. Penelitian ini penulis angkat karena sangat tertarik 
dengan distrik Mandau yang merupakan bagian dari wilayah Kerajaan Siak dan menjadi salah satu wilayah tersebarnya ajaran tarekat Naqsyabandiyah yang turut dikembangkan oleh tuan Syekh H. Imam Sabar Al-Kholidi Naqsyabandi bin Encik Coteih. Penelitian ini belum banyak dikaji dan dipublikasikan untuk memperluas khazanah keilmuan bagi khalayak masyarakat. Adapun rumusan masalah dari penelitian ini yaitu; 1) Bagaimana sejarah tarekat Naqsyabandiyah di Indonesia khususnya di Onder Distrik Mandau Kerajaan Siak? Bagaimana peran tuan Syekh H. Imam Sabar Al-Kholidi Naqsyabandi bin Encik Coteih dalam mengembangkan ajaran tarekat Naqsyabandiyah di Onder Distrik Mandau khususnya di desa Balai Pungut. Penelitian ini bertujuan untuk mengetahui sejarah tarekat Naqsyabandiyah di Indonesia secara umum dan Onder Distrik Mandau pada masa Kerajaan Siak. Mengetahui peranan tuan Syekh H. Imam Sabar Al-Kholidi Naqsyabandi bin Encik Coteih dalam mengembangkan ajaran tarekat Naqsyabandiyah di Onder Distrik Mandau khususnya di desa Balai Pungut.

\section{Medote Penelitian}

Metode berarti cara, jalan, atau petunjuk pelaksanaan atau petunjuk teknis. Adapun yang dimaksud dengan penelitian menurut Hilbish adalah penyelidikan yang seksama dan teliti terhadap suatu subjek untuk menemukan fakta-fakta guna menghasilkan produk baru, memecahkan suatu masalah, atau untuk menyokong atau menolak suatu teori (Abdurahman, 2011: 100). Jenis penelitian ini adalah penelitian kualitatif, artinya suatu jenis penelitian yang berusaha memberikan penjelasan dengan gambaran mengenai berbagai macam data yang telah dikumpulkan dari objek penelitian yang berkaitan dengan sejarah tarekat Naqsyabandiyah distrik Mandau Kerajaan Siak: Tuan Syekh H. Imam Sabar Al-Kholidi Naqsyabandi.

Pendekatan yang digunakan adalah pendekatan deskriptif dimana data diperoleh melalui observasi, wawancara, dan studi dokumentasi. Kemudian yang menjadi sumber data dalam penelitian ini adalah sumber tertulis, tidak tertulis, dan sumber lisan. Sumber tertulis, berupa jurnal, buku-buku, skripsi, dan tulisan/catatan-catatan yang dianggap relevan dengan penelitian ini. Sumber tidak tertulis berupa bukti fisik yang berkaitan dengan tarekat Naqsyabandiyah di Onder Distrik Mandau tepatnya di desa Balai Pungut. Dalam tahap ini penulis melakukan pencarian data dengan langsung terjun ke desa Balai Pungut. Adapun bukti-bukti fisik yang dapat ditemukan meliputi keberadaan desa tersebut, 
adanya rumah suluk, serta makam Tuan Syekh H. Imam Sabar Al-Kholidi Naqsyabandi. Sumber lisan: berupa informasi yang diperoleh melalui wawancara dengan narasumber.

\section{Pembahasan}

\section{Sejarah Tarekat Naqsyabandiyah Pada Masa Kerajaan Siak di Indonesia}

Tarekat Naqsyabandiyah sudah ada di Indonesia sejak dua abad sebelum Belanda mengenalnya untuk pertama kali - kendatipun bentuk tarekat itu mungkin berbeda. Ulama dan sufi Indonesia yang pertama sekali menyebut tarekat ini dalam tulisan-tulisannya adalah Syaikh Yusuf Makassar (1626-1699) yang masyhur itu (Van Bruinessen, 1992: 34). Di Indonesia, berkembang beberapa tarekat diantaranya adalah Naqsyabandiyah. Naqsabandiyah adalah tarekat yang paling banyak pengikutnya di Indonesia. Tarekat ini tidak hanya tersebar di kalangan penduduk, tetapi juga menjadi bagian yang sangat penting dalam kebangkitan politik Islam pada abad ke-19. Tarekat dalam bentuk ini memiliki tiga cabang yaitu; Mazhariyah, Khalidiyah, dan Qadiriyah. Tarekat yang berbentuk Qadiriyah Naqsabandiyah merupakan penggabungan dua tarekat yang diciptakan oleh seorang sufi bernama Ahmad Khatib Sambasi dari Kalimantan sekitar pertengahan abad ke-19. Tujuan tarekat adalah mendekatkan diri kepada Allah agar bisa melihat ( $m a$ 'rifah) atau bahkan bersatu (al-ittihad) dengan Allah (tajalli) (Siregar, 2009: 180).

Untuk mengetahui lebih jauh, tentu perlu mencari bukti bagaimana tarekat ini telah berkembang dan diamalkan di Indonesia pada abad ke-19. Laporan-laporan yang diberikan sebelum Snouck memberikan bukti bahwa tarekat jenis ini telah tersebar di Cianjur, Sumedang dan Sukabumi. Bahkan di Cianjur, menurut informasi, seluruh bangsawan telah ikut bergabung dengan tarekat Naqsyabandiyah. Bupati dan penghulu kepala Cianjur sendiri adalah seorang pengikut Naqsyabandiyah, dan beberapa saudaranya lebih memilih menjadi guru tarekat. Informasi lain dari van den Berg (1883) mengatakan bahwa tarekat Naqsyabandiyah juga telah diamalkan dan dijalankan oleh orang Aceh, Jawa Tengah dan Jawa Timur. Perkembangan tarekat Naqsyabandiyah yang lebih nyata adalah ketika Syaikh Ahmad Khatib Sambas (w. 1878) memperkenalkan tarekat baru hasil ciptaanya sendiri sekitar tahun 1850-an yaitu tarekat Qadiriyah Naqsabandiyah. Dengan peranan muridnya, Syaikh Abdul Karim dari Banten, tarekat ini juga menjadi sangat populer di Banten, khususnya jika dilihat di kalangan penduduk ekonomi rendah di desa-desa. Di samping itu, tarekat Naqsabandiyah Khalidiyah juga memperlihatkan daya tariknya berkat pengaruh 
Syaikh Ismail Minangkabau di Riau dan di Sumatera Barat sekitar tahun 1860-an (Noupal, 2016: 303).

Proses pembelajaran dalam tarekat berkaitan dengan hubungan antara guru dan murid. Guru dalam tarekat disebut Syekh, dan wakilnya diberikan sebutan khalifah serta untuk pengikutnya disebut Salik (mahasiswa). Tarekat juga disebut ribath atau zawiyah atau taqiya. Setiap tarekat memiliki praktik atau ajaran agama tertentu, simbol kelembagaan, aturan, dan upacara lainnya. Berdasarkan ketentuan tarekat pada umumnya, bahwa seorang Syaikh sangat menentukan terhadap murid-muridnya. Kehadiran seorang murid di depan gurunya seperti bangkai yang mati atau tak berdaya. Karena tarekat adalah cara mendekatkan diri kepada Allah maka orang yang menempuh jalan tersebut harus menjalankan syariat (Amrizal \& Astafi, 2019: 85).

Tarekat Naqsyabandiyah merupakan aliran keagamaan dalam agama Islam yang telah tumbuh dan berkembang selama berabad-abad di daerah Riau serta pulau Sumatra pada umumnya. Jika ditinjau untuk di Riau sendiri itu berpusat di Kerajaan Siak. Tarekat ini telah memberikan perintah agar pemeluk atau pengikutnya melakukan sejumlah upacara ritual di luar kewajiban-kewajiban yang dilakukan oleh para pengikut aliran sunnah, seperti kegiatan-kegiatan berzikir dan wirid, berpuasa dan mengasingkan diri serta taat kepada guru/mursyid/khalifah. Orang-orang yang telah menjalankan upacara-upacara ritual keagamaan yang telah di bombing oleh seorang guru atau khalifah dan dianggap telah menyelesaikannya dengan baik dinamakan khalifah. Hal tersebut dikarenakan menurut para pemeluk tarekat tersebut seorang khalifah itu dilihat sebagai orang yang memliki banyak pengetahuan tentang agama Islam serta sebagai seseorang yang mempunyai kekuatan gaib dan sanggup mengatur, mengendalikan dan menguasai makhluk-makhluk gaib yang berada disekitar kehidupan manusia. Maka, dimata para pemeluk atau pengikut tarekat ini, kedudukan sosial seorang khalifah itu sangatlah tinggi. Dimasa lampau para khaifah inilah yang sebenarnya telah mengislamkan maysarakat sakai di Kecamatan Mandau (Suparlan, 1995: 197).

Peta pengembangan tarekat Naqsyabandiyah, pada masa kesulthanan Siak pertama kali berpusat pada Distrik Bagan Siapi- api dan Distrik Siak. Dukungan dan dorongan yang besar dari Sultan Siak merupakan faktor yang memiliki andil besar yang menyebabkan ajaran tarekat tersebut sampai saat ini masih mewarnai aliran atau paham keagamaan di berbagai lapisan masyarakat. Usaha Sultan dalam merekrut dan mengajak orang-orang 
tarekat Naqsyabandiyah ini memiliki dua tujuan. Pertama, untuk mendidik di berbagai lembaga pendidikan, kedua, untuk tujuan khusus yaitu melakukan pengembangan ajaran tarekat, serta ketiga, untuk mendakwahkan ajaran Islam di tengah-tengah masyarakat, terutama di daerah terpencil. Berdasarkan registrasi guru agama pada tahun 1930 terdapat 57 orang guru yang mendapat izin untuk mengajar pada tiga Distrik, masing-masing yaitu 44 guru pada Distrik Bagan Siapi-api, 8 guru pada Distrik Pekanbaru, 5 guru pada Distrik Selat Panjang (termasuk didalamnya distrik Mandau) dan 29 dari semuanya adalah guruguru yang mengajarkan tarekat (Abduh, 2012: 232).

Dari perjalanan sejarah pengembangan tarekat Naqsyabandiyah dalam wilayah Kesultanan Siak, ada tiga persoalan yang sangat signifikan untuk dideskripsikan, yaitu; 1) Islamisasi masyarakat pedalaman; 2 Menumbuhkan, mengembangkan dan mempertahankan amalan keagamaan tradisional; 3) Menepas dakwah penyeberan agama lainnya (Abduh, 2009: 385).

Proses islamisasi pada masyarakat yang tinggal di derah pedalaman diperkirakan telah dimulai dalam kisaran tahun 1912, Khalifah Ibrahim yang menjadi utusan tuan guru Syekh Abdul Wahab Rokan mendapatkan izin dari Sultan Siak untuk menumbuhkembangkan tarekat pada Distrik Bagan Siapi-api. Distrik Bagan Siapi-api merupakan suatu distrik yang bersebelahan dan berbatasan dengan onderdistrik Mandau yang sampai saat ini dikenal sebagai daerah pemukiman orang pedalaman (Sakai). Orang Sakai merupakan suatu kelompok masyarakat yang egalitarian, hidup terasing, terpencil dan terdalam di sekitar hulu-hulu sungai, di tepi-tepi mata air dan rawa-rawa. Pada intinya mereka mencari tempat tinggal di daerah sumber air atau yang memilki pasokan air. Dari Distrik Bagan Siapi-api inilah para khalifah tarekat Naqsyabandiyah kemudian melakukan penelusuran atau penjelajahan dengan mengikuti alur sungai Rokan dan kemudian menyinggahi berbagai pemukiman masyarakat yang dilalui. Para khalifah berjuang tanpa henti sampai pada akhirnya telah membuahkan hasil yang sampai saat ini memberi warna tersendiri bagi corak pengamalan dan pelaksanaan Islam mayoritas masyarakat Melayu Riau. Hal tersebut kemudian terbukti karena ajaran tarekat ini pada saat sekarang telah menyebar di beberapa daerah daratan Riau terutama pada Kabupaten Pelalawan, Bengkalis, Siak, Kampar dan Pangkalan Kerinci serta Kota Dumai. Keberadaan tarekat Naqsyabandiyah yang konsisten dalam melaksanakan pengembangan ajaran Islam sufistik terutama melalui rumah (madrasah) suluk (nosa) telah menjadi penguat tersendiri dalam 
mempertahankan keyakinan beragama serta nilai-nilai Islam dari propaganda agama lainnya (Abduh, 2009: 385).

\section{Gambaran Ringkas Distrik Mandau}

Berdasarkan hasil pencaharian data, penulis menemukan bahwa Mandau merupakan nama anak sungai yang bermuara atau berakhir ke sungai Siak, menghampar dari Timur ke Barat yang kemudian menjadi nama suatu daerah yaitu daerah Mandau. Pada masa kerajaan Siak daerah ini dikenal dengan sebutan onder Distrik Mandau. Pada saat itu, onder distrik Mandau merupakan daerah yang mempunyai peraturan atau hukum sendiri yang disahkan oleh sultan Siak sendiri. Mengamati dari hal inilah, kita meninjau akar sejarah Mandau sebelum kerajaan Siak pada tahun 1723 M dimana Mandau sudah ditinggali oleh sekelompok manusia yang dikenal dengan sebutan Suku Ando Nan Sembilan Puluh Sembilan dan pada akhirnya resmi menjadi suku Mandau.

Tanah Mandau dipimpin oleh seorang penghulu yang dikenal Penghulu Mandau. Kejadian ini terjadi sebelum Mandau kemudian jatuh ke pangkuan kerajaan Siak. Jadi, pada waktu itu sungai Mandau bernama Sungai Kemuning atau Sungai Embun yang memiliki arti sungai seakan-akan lengang dan sunyi sebab tidak banyak manusia yang menghuninya dan mereka belum pandai dalam membuat perahu atau sampan. Berdasarkan cerita-cerita masyarakat dulu, kekuasaan penghulu Mandau ini sangatlah luas. Hal ini dibuktikan dengan beberapa perbatasan yang terdapat di sekitarnya, seperti berbatasan langsung dengan Distrik Siak, Onder Distrik Tapung, Onder Distrik Tanah Putih, dan Onder Distrik Bukit Batu. Sungai Kemuning mulai dikenal serta berfungsi bagi penduduk sebagai penghubung dan tempat mencari kehidupan. Sungai ini kemudian dikenal dengan nama sungai Mandau yang pada saat itu berada di bawah kekuasaan Penghulu Ando yang kemudian menjadi Penghulu Mandau atau Penghulu Puncak. Jejak sejarah Mandau ini tidak dapat dipisahkan begitu saja dari seorang sosok bersahaja yang dikenal sebagai Boedjang Ganti, Bathin Kampoeng Djamban (Bathin Delapan) onderdistrict Mandau, tahun 1940 (Ashsubli, 2016: 53).

\section{Pengembangan Tarekat Naqsyabandiyah Syekh H. Imam Sabar Al-Kholidi Nasyabandi di Desa Balai Pungut}

Berdasarkan hasil observasi, di peroleh data bahwa desa Balai Pungut ini merupakan sebuah desa yang berada di Kecamatan Pinggir Kabupaten Bengkalis. Desa ini memiliki 
dua Dusun yaitu Dusun Balai dan Dusun Pungut. Untuk sampai ke Desa ini, jika kita melakukan perjalanan menggunakan kendaraan roda dua, dari pusat kota Duri itu memerlukan waktu sekitar 45 Menit dengan jarak tempuh 35 Kilometer. Jika kita telisik lebih jauh, desa Balai Pungut ini memiliki jejak sejarah yang sangat menarik salah satunya adalah pada masa Kerajaan Siak Sri Indrapura. Balai pungut memegang peranan penting sebagai salah satu daerah yang pada saat itu berperan sebagai tempat dikumpulkan atau dipungutnya hasil-hasil bumi. Hasil-hasil bumi yang telah dikumpulkan itu kemudian disimpan di Balai Desa. Balai desa tersebut terletak di tepi Sungai Mandau. Seperti ulasan tadi, sungai Mandau merupakan salah satu jalur perdagangan yang bisa dikatakan cukup sibuk pada masa Kerajaan Siak Sri Indrapura. Hal tersebut yang membuat pada akhirnya desa ini disebut atau dikenal dengan nama Balai Pungut.

Desa Balai Pungut menjadi saksi nyata akan berkembangnya ajaran tarekat Naqsyabandiyah di wilayah Mandau khususnya itu pada masa Kerajaan Siak Sri Indrapura oleh tuan Syekh H. Imam Sabar Al-Kholidi Naqsyabandi bin Encik Coteih. Sedikit pemapaan biografi, beliau lahir pada tahun $1878 \mathrm{M}$ yang biasa dipanggil dengan sebutan Tuan Guru. Tuan guru merupakan sebutan yang setara dengan derajat ulama. Ulama adalah warasat al-anbiya yaitu pewaris ilmu dan pelanjut "estapet" perjuangan Nabi Muhammad Saw. Itulah mengapa mereka sangat dihormati kaum Muslimin lainnya (Wathoni, 2021: 3). Beliau melakukan pengembangan ajaran agama Islam pertama dengan jalur Tarekat Naqsyabandiyah di wilayah Mandau.

Tarekat Naqsyabandiyah mulai ada dan diketuai langsung oleh Syekh H. Imam Sabar Al-Kholidi Naqsyabandi untuk pertama kalinya itu pada tahun 1925 M di Desa Beringin, Kecamatan Mandau, yang saat ini berada di distrik Talang Muandau (Amrizal \& Astafi, 2019: 86). Beliau diangkat oleh Datuk atau Camat "Entol" di Desa Beringin. Tepat pada tahun 1931 M, beliau mengajukan permohonan kepada Sultan Siak untuk diberikan izin dalam mengembangkan ajaran agama Islam jalur Tarekat Naqsyabandiyah di wilayah Kecamatan Mandau. Setelah diuji dan diteliti, ternyata ajaran yang dikembangkan oleh Tuan Syekh H. Imam Sabar Al-Kholidi Naqsyabandi ini benar-benar menurut syariat serta tidak mendatangkan pertentangan terhadap kerajaan. Berdasarkan pertimbangan tersebut, Sultan kemudian memberikan izin untuk pengembangan ajaran ini di wilayah kerajaan Siak tepatnya di onder distrik Mandau. 
Berdasarkan laporan yang ditulis oleh Syekh Usman (putra Syekh Imam Sabar AlKholidi Naqsyabandi), setelah mendapatkan izin dari Sultan, Syekh H.Imam Sabar AlKholidi Naqsyabandi mulai menanamkan akidah-akidah Islam ajaran-ajaran yang berlandaskan Al Qur'an dan sunnah Rasulullah SAW. Adapun masyarakat yang dibinanya saat itu terdiri dari suku-suku asli dan suku sakai/ bathin (Amrizal, 2019).

Pada permulaan Syekh H. Imam Sabar Al-Kholidi Naqsyabandi menanamkan akidah dan membina suku-suku Bathin dengan mengislamkannya serta ditaubatkan, termasuk suku Akik Peguling di perairan sungai Mandau. Dalam menjalankan tugas atau kewajiban ini, tidak begitu saja berjalan mulus, beliau juga mendapatkan pertentangan dan hambatan dari masyarakat setempat. Pertentangan tersebut datang dari beberapa suku, diantaranya suku Minas, Penaso, dan Belutu. Beliau mengupayakan secara perlahan-lahan untuk merubah kepercayaan masyarakat yang awalnya masih berpegang pada kepercayaan asli atau primitif yaitu animisme dengan menanamkan kesadaran untuk berakidah atau memiliki kepercayaan berlandaskan Al-qur'an dan sunnah Rasulullah SAW. yakni dengan ilmu-ilmu syariat. Perjuangannya pada akhirnya membuahkan hasil. Suku-suku sakai dan suku Akik Peguling telah banyak yang menganut ajaran agama Islam bahkan mematuhi ajaran Tariqhat Naqsyabandiyah.

Perjuangan yang harus dilalui oleh tuan Syekh H. Imam Sabar Al- Kholidi Naqsyabandi tidaklah mudah. Beliau banyak mendapatkan hambatan dan tantangan yang semakin membuat beliau harus kuat. Hambatan/ tantangan yang dimaksud datang dari suku-suku seperti dalam suku Minas yaitu kelompok Bathin Takah, suku Penaso dalam kelompok Bathin Ganggang, dan suku Belutu dalam kelompok Bathin Babut. Hambatan dan tantangan yang datang ini tidak begitu saja membuat beliau mundur. Dengan cara perlahan-lahan suku-suku tadi akhirnya dapat mempercayai kemudian menganut agama Islam dan meninggalkan kepercayaan mereka.

Disaat semua masyarakat desa dan suku-suku Sakai serta suku Akik Peguling telah banyak yang berpegang pada ajaran agama Islam bahkan, mematuhi ajaran tarekat Naqsyabandiyah maka, tuan Syek H. Imam Sabar Al-Kholidi Naqsyabandi menghadap sekaligus melaporkan kepada Sultan Syarif Qasim Kerajaan Siak Sri Indrapura bahwa bathin-bathin yang lima telah ditaubatkan. Mendengar hal tersebut, Sulthan kemudian memberikan penghargaan kepada beliau dengan diberikan kekuasaan dan diangkat sebagai hakim untuk wilayah kecamatan Mandau. Maka, setiap Datuk Distrik Mandau 
mengadakan Sidang, beliau diwajibkan untuk menghadirinya dan kemudian diberikan benefit oleh Sulthan.

Pada tahun 1936 M, Syekh H. Imam Sabar kemudian pergi meninggalkan Desa Beringin dan menuju ke Desa Balai Pungut atas perintah dari gurunya yang bernama Imam Besar Kota Intan. Kemudian, pada tahun 1937 M barulah beliau mulai mengembangkan serta membina ajaran syari'at di wilayah desa Balai Pungut tepatnya di Darun Tandun pada waktu itu. Banyak upaya yang telah dilakukan oleh beliau demi perkembangan ajaran ini. Surau atau mushalla kecil juga turut didirikan dan mulai memiliki beberapa pengikut. Disaat ajaran ini sudah mulai mengalami perkembangan dan dikenal oleh khlayak masyarakat terjadi sebuah peristiwa yang menyebabkan kemunduran tepatnya sekitar tahun 1941 M, Jepang memasuki wilayah Kecamatan Mandau. Dengan masuknya Jepang ini, kegiatan-kegiatan yang diilakukan seperti kegiatan Suluk mulai pecah atau bubar. Hal ini terjadi karena mereka tidak merasa aman. Kebanyakan masyarakat terpencar-pencar dalam keadaan kelaparan dan memprihatinkan. Melihat kondisi yang seperti ini, pada tahun 1942 M, Tuan Syekh meninggalkan Tandun dan pindah ke tengah-tengah Desa Balai Pungut.

Setelah berbagai peristiwa terjadi dalam beberapa rentang waktu, pada tahun $1947 \mathrm{M}$ Syekh H. Imam Sabar kemudian diangkat menjadi wali hakim untuk desa Balai Pungut, Tengganau, Pinggir, Bolutu dan Kandis. Karena hal tersebut, pada tahun 1951 M beliau mendapatkan mufakat serta memulai lagi mengembangkan ajaran tarekat Naqsyabandiyah dengan mengadakan khalwat/ suluk di Balai Pungut dan seterusnya. Beberapa tahun kemudian tepatnya pada tahun 1954 M tuan Syekh H. Imam Sabar juga mengadakan khalwat/ suluk di desa Beringin sehingga beliau memimpin dua persulukan yaitu di desa Balai Pungut dan desa Beringin. Rumah Suluk pertama yang didirikan oleh Syekh Imam Sabar, berada di pinggir Desa Balai Pungut sekitar tahun 1931, yang bernama Rumah Suluk al-Tahrim. Setelah itu, ia mendirikan masjid yang kini menjadi tapak Masjid Baldatun. Puluhan jamaah yang mengikuti serta belajar tarekat darinya berasal dari keluarga dan masyarakat sekitar suku Sakai dan Suku Melayu Mandau (Amrizal \& Astafi, 2019: 88). Kegigihan dan perjuangan beliau dalam menumbuh-kembangkan ajaran agama Islam tarekat Naqsyabandiyah di distrik Mandau khususnya di desa Balai Pungut ini telah berhasil membina 11 orang muridnya, yaitu; 1) Kh. Usman, 2) Kh. Zakaria, 3) Kh. Muhammad 'Ali, 5) Kh. M. Yusuf, 6) Kh. Yunus, 7) Kh. Muhammad, 8) Kh.Umar, 9) Kh. Daud, 10) Kh. Yahya, dan 11) Kh. Muhammad Nur. 
Setelah melalui proses panjang dalam kehidupannya, Syekh H. Imam Sabar AlKholidi Naqsyabandi berpulang kepada sang Khalik, Allah SWT. pada tanggal 7 Mei 1960 dan dimakamkan di desa Balai Pungut. Setelah tujuh hari Almarhum wafat, datanglah beberapa murid dari beliau yaitu Khalifah Muhammad Ali selaku kepala desa waktu itu, Khalifah M. Yusuf, Khalifah Yunus dan Khalifah Muhammad. Keempat khalifah tersebut sebagai wakil dari para murid dan Jemaah Almarhum yang lainnya, menunjuk Syekh Usman sebagai anak kandung almarhum untuk menggantikan dari pada Almarhum. Syekh Usman kemudian dilantik pada tanggal 17 April 1962. Terkait dengan makam Syekh H. Imam Sabar Al- Kholidi Naqsyabandi, makam itu akan dijadikan sebagai salah satu destinasi wisata sejarah Islam provinsi Riau (Wawancara dengan Majrun, Noivember 2021).

\section{Kesimpulan}

Di Indonesia, bekembang beberapa tarekat diantaranya adalah Naqsyabandiyah. Naqsabandiyah adalah tarekat yang paling banyak pengikutnya di Indonesia. Tarekat ini tidak hanya tersebar di kalangan penduduk, tetapi juga menjadi bagian yang sangat penting dalam kebangkitan politik Islam pada abad ke-19. Tarekat Naqsyabandiyah merupakan aliran keagamaan dalam agama Islam yang telah tumbuh dan berkembang selama berabadabad di daerah Riau serta pulau Sumatra pada umumnya. Jika ditinjau untuk di Riau sendiri itu berpusat di Kerajaan Siak. Tarekat ini telah memberikan perintah agar pemeluk atau pengikutnya melakukan sejumlah upacara ritual di luar kewajiban-kewajiban yang dilakukan oleh para pengikut aliran sunnah, seperti kegiatan-kegiatan berzikir dan wirid, berpuasa dan mengasingkan diri serta taat kepada guru/mursyid/khalifah. Peta pengembangan tarekat Naqsyabandiyah, pada masa kesulthanan Siak pertama kali berpusat pada Distrik Bagan Siapi-api dan Distrik Siak. Dukungan dan dorongan yang besar dari Sultan Siak merupakan faktor yang memiliki andil besar yang menyebabkan ajaran tarekat tersebut sampai saat ini masih mewarnai aliran atau paham keagamaan di berbagai lapisan masyarakat. Sejarah perkembangan tarekat Naqsyabandiyah ini juga terjadi di wilayah Mandau. Pada masa kerajaan Siak daerah ini disebut Ondor Distrik Mandau. Di onder distrik Mandau ini, perkembangan ajaran tarekat Naqsyabandiyah untuk pertama kalinya dikembangkan oleh seorang tokoh yang bernama Syekh H. Imam Sabar Al- Kholidi Naqsyabandi yang mengkhususkan wilayah di Desa Balai Pungut sebagai sebuah desa 
yang turut andil dalam memberikan pasokan kebutuhan ke Kerajaan Siak melalui jalur Sungai Mandau. Tarekat Naqsyabandiyah mulai ada dan diketuai langsung oleh Syekh H. Imam Sabar Al-Kholidi Naqsyabandi untuk pertama kalinya itu pada tahun $1925 \mathrm{M}$ di Desa Beringin, Kecamatan Mandau dan baru pada tahun 1937 M barulah beliau mulai mengembangkan serta membina ajaran syari'at di wilayah desa Balai Pungut tepatnya di Darun Tandun pada waktu itu. Rumah Suluk pertama yang didirikan oleh Syekh Imam Sabar, berada di pinggir Desa Balai Pungut sekitar tahun 1931 bernama Rumah Suluk alTahrim. Setelah perjuangan panjangnya ini beliau kemudian berpulang kerahmatullah pada tanggal 7 Mei 1960 dan dimakamkan di Desa Balai Pungut.

\section{Daftar Rujukan}

Abduh, M. A. (2009). Menelusuri Akar Sejarah dan Aktivitas Jamaah Tarekat Naqsyabandiyah di Kabupaten Pelalawan. Al-Fikra: Jurnal Ilmiah Keislaman, 8(2), 382-395. http://dx.doi.org/10.24014/af.v8i2.3816.

Abduh, M. A. (2012). Peran Tarekat Naqsyabandiyah Khalidiyyah Syekh Abdul Wahab Rokan (Dalam Dakwah dan Pendidikan Islam di Riau dan Sumut). Al-Fikra: Jurnal Ilmiah Keislaman, 11(2), 206-246. https://doi.org/10.24014/af.v11i2.3858.

Abdurahman, D. (2011). Metodologi Penelitian Sejarah Islam. Yogyakarta: Penerbit Ombak.

Amrizal, (2019). Mengenal Tuan Syekh H. Imam Sabar, Salah Seorang Pengembang Islam di Onder Distrik Mandau. https://bedenai.blogspot.com/2019/09/mengenal-tuansyekh-h-imam-sabar-salah.html.

Amrizal, A., \& Astafi, R. (2019). The existing of naqshbandi tariqa and its influence on socio-cultural life of the sakai people in Bengkalis regency. Wawasan: Jurnal Ilmiah Agama dan Sosial Budaya, 4(1), 80-93. https://doi.org/10.15575/jw.v4i1.4072.

Ashsubli, M. (2016). Dinamika gerakan pembentukan daerah otonom baru Kabupaten Mandau Riau. Otoritas: Jurnal Ilmu Pemerintahan, 6(1), 50-59. https://doi.org/10.26618/ojip.v6i1.41.

Hidayat, Z. (2015). Tarekat Naqsyabandiyah-Khalidiyah Babussalam (TNKB) dari Doktrin, Seni Hingga Arsitektur. Jakarta: Lembaga Studi Islam Progresif (LSIP).

Iskandar, J. (2018). Kegiatan suluk tarekat naqsyabandiyah didesa Medan Jaya Kecamatan Ipuh Kabupaten Mukomuko. Skripsi. Institut Agama Islam Negeri (IAIN) Bengkulu.

Madjid, M. D., \& Wahyudhi, J. (2014). Ilmu Sejarah: Sebuah Pengantar. Jakarta: Kencana.

Noupal, M. (2016). Tarekat Naqsabandiyah di Indonesia Abad ke-19 dari Ortodoksi ke Politisasi. Intizar, 22(2), 297-318.

Shihab, A. (2001). Islam Shufistik, Islam Pertama dan Pengaruhnya hinggi Kini di Indonesia. Bandung: Mizan. 
Siregar, L. H. (2009). Sejarah Tarekat dan Dinamika Sosial. Jurnal: MIQOT, 33(2), 169187.

Siregar, L. H. (2011). Tarekat Naqsyabandiyah Syaikh Abdul Wahab Rokan: Sejarah, Ajaran, Amalan, dan Dinamika Perubahan. Miqot: Jurnal Ilmu-Ilmu Keislaman, 35(1), 59-77.

Suparlan, P. (1995). Orang Sakai di Riau: Masyarakat Terasing dalam Masyarakat Indonesia. Jakarta: Yayasan Obor Indonesia.

Suteja, S. (2016). Tasawuf di Nusantara Tadarus Tasawuf \& Tarekat. Cirebon: CV. Aksarasatu.

Van Bruinessen, M. (1992). Tarekat Naqsyabandiyah di Indonesia. Bandung: Mizan.

Wathoni, L. M. N. (2021). Tuan Guru Haji Lalu Anas Hasyri: Kharisma dan Kontribusinya Mengembangkan Nadhlatul Wathan. Mataram: Institute Bale Institute. 